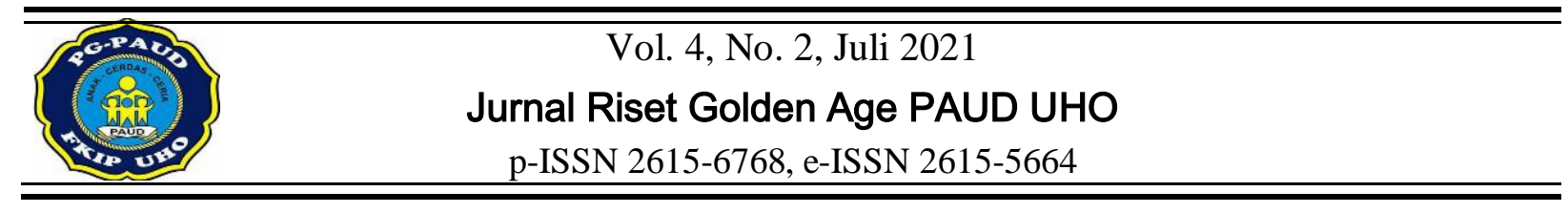

\title{
PERILAKU AGRESIF ANAK USIA DINI
}

\author{
Mastuinda $^{1)^{*}}$, Dadan Suryana ${ }^{1)}$ \\ ${ }^{1}$ Program Studi PAUD, Universitas Negeri Padang. Jl. Prof. Dr. Hamka, Padang 25100, Indonesia. \\ *Email: mastuinda06@gmail.com
}

\begin{abstract}
Abstrak
Penelitian ini bertujuan untuk mendeskripsikan perilaku agresif yang dimunculkan oleh anak usia dini. Metode yang digunakan dalam penelitian ini adalah metode penelitian deskriptif kualitatif dengan studi literatur. Dalam penelitian studi literatur ini peneliti melakukan pengumpulan data dengan mengumpulkan dan menganalisis berbagai sumber tertulis seperti artikel, jurnal, dan buku yang relevan dengan penelitian dalam penelitian ini. Hasil penelitian studi literatur ini, menjelaskan tentang perilaku agresif anak adalah salah satu bentuk kurang tepatnya anak belajar sosial, karena perilaku ini dapat merugikan diri anak dan orang lain, faktor penyebab munculnya perilaku agresif pada anak terbagi dua yaitu faktor internal dan faktor eksternal sedangkan penanganan perilaku agresif anak usia dini perlu disesuaikan dengan penyebab terjadinya perilaku dan membutuhkan kerjasama dari berbagai pihak baik dari orang tua, guru, maupun lingkungan masyarakat.
\end{abstract}

Kata kunci: anak usia dini, faktor penyebab, penanganan, perilaku agresif.

\section{EARLY CHILDHOOD AGGRESSIVE BEHAVIOR}

\begin{abstract}
This study aims to describe the aggressive behavior raised by early childhood. The method used in this research is descriptive qualitative research method with literature study. In a literature study, researchers conducted data research by collecting and analyzing various sources of written articles, journals and books relevant to the research in this study. The results of this literature study explain that children's aggressive behavior is an inappropriate form of social learning, because this behavior can harm themselves and others, the factors that cause aggressive behavior in children are divided into two, namely internal factors and external factors in handling children's aggressive behavior. Early childhood cannot be defeated by various incidents of behavior and cooperative relationships on the part of both parents, teachers, and the community.
\end{abstract}

Keywords: early age, causative factors, behavior, aggressive.

\section{PENDAHULUAN}

Anak usia dini merupakan suatu titipan oleh Allah SWT yang mana harus dilindungi dan dibimbing dengan baik. Setiap orang tua memiliki kewajiban untuk mangasuh dan memberikan pendidikan yang layak. Pendidkan sangat perlu diberikan pada anak sejak dini karena anak berada pada masa keemasannya (Ariyanti, 2016). Disebut masa keemasan karena pada usia 0-8 tahun terjadi perkembangan yang sangat penting pada anak yaitu pertumbuhan fisik anak, kognitif, emosi dan sosial yang harus distimulasi sejak dini agar berkembang secara optimal (Suryana, 2014). Masa keemasan ini terjadi hanya satu kali dalam kehidupan manusia dan tidak dapat ditunda pada pada periode selanjutnya. (Suryana et al., 2018)

Pendidikan anak dimulai sejak dini yaitu dimulai dari lingkungaan terdekat anak. Setiap anak tumbuh dan berkembang menyesuaikan dengan karakter perilaku dari lingkungannya. Dalam dunia pendidikan ada tiga lingkungan yang dekat dengan anak: (1) lingkungan keluarga, (2) lingkungan sekolah, dan (3) lingkungan masyarakat. Ketiganya saling berkaitan mempengaruhi pembentukan karakter atau keperibadian anak usia dini (Mansur, 2018). Pada dasarnya pendidikan yang diberikan kepada anak usia dini lebih fokus untuk menyiapkan lingkungan yang baik dan kondusif untuk anak, bukan untuk menyiapkan anak untuk belajar. Karena lingkungan yang baik dan 
positif akan mampu mengembangkan multiple intelligent (kecerdasan ganda) yang dimiliki anak, sehingga menjadi potensi bagi anak dimasa yang akan datang (Suryana, 2016)

Bayi yang baru lahir membawa berbagai potensi dalam dirinya salah satunya adalah potensi sosialitas (Suryana, 2013a). Potensi ini akan berkembang sesuai dengan stimulasi yang diberikan oleh orang tua anak sebagai orang terdekat anak. Albert bandura dalam teori belajar sosialnya menjelaskan bahwa perilaku yang dimunculkan anak adalah hasil peniruan dari perilaku orang dewasa yang berada di dekat anak. Anak yang diasuh dalam suatu lingkungan keluarga yang baik akan membentuk perilaku yang baik, sebaliknya anak yang diasuh dalam dilingkungan keluaga yang kurang baik akan membentuk perilaku kurang baik pula (Laila, 2015). Oleh karena itu sebisa mungkin orang tua harus memberikan lingkungan yang baik pada anak dengan memunculkan perilaku yang baik untuk ditiru anak.

Agresivitas adalah suatu perilaku yang menjadi sebuah fenomena umum yang terjadi di masyarakat baik dilakukan oleh orang dewasa, remaja maupun anak usia dini. Menurut (Berkowitz, 1995) tindakan kekerasan yang terjadi sebagai salah satu bentuk perilaku agresif dapat terjadi di seluruh belahan dunia dan dilakukah seluruh lapisan masyarakat baik tua maupun muda dengan bentuk yang semakin kompleks dan beragam. Oleh sebab itu perilaku agresif bukan hanya dimunculkan orang dewasa namun anak-anak juga dijumpai dengan melihat anak yang suka menyerang dan mengakibatkan kerugian pada orang lain.

Anak-anak mulai berkenalan dan belajar untuk menghadapi kekecewaan saat apa yang diinginkan tidak bisa terpenuhi. Perasaan kekecewaan yang dirasakan oleh anak sering kali tanpa sadar ditahan oleh orang tua. Misalnya saat anak menangis karena kecewa, orang tua dengan berbagai cara mencoba menghibur, mengalihkan dan terkadang orang tua justru memarahi anak agar berhenti menangis. Tindakan dari orang tua ini membuat emosi anak tidak tersalurkan secara bebas. Jika ini terjadi terus menerus, memicu munculnya perilaku agresif. (Suryana \& Yolanda, 2018)

Perilaku agresif yang dimunculkan oleh anak usia dini merupakan perilaku yang maladaptif. Perilaku ini dipengaruhi oleh beberapa faktor yaitu faktor keluarga, sosial budaya, sekolah, dan kepribadian. Selain itu juga dipengaruhi oleh usia, pengalaman, jenis kelamin, dan status sosial ekonomi (Nesbit et al., 2007)

Kasus-kasus perilaku agresif pada anak semakin meningkat sejalan dengan meningkatnya kasus kekerasan. Hal ini diungkapkan oleh survei nasional yang dilaksanakan oleh kementerian PPPA pada tahun 2018 mengenai kekerasan terhadap anak, hasil survey menemukan bahwa $62 \%$ anak perempuan dan lelaki mengalami satu atau lebih dari satu bentuk kekerasan sepanjang hidupnya. Data lainnya mengungkapkan bahwa anak Indonesia yang mengalami kekerasan menyebabkan mereka terpapar agresi psikologis. Bagi anak perilaku agresif merupakan hal yang wajar untuk mengatasi masalahnya. Namun hal tersebut dinilai sebagai kesalahan dalam belajar sosial sebagaimana diuangkapkan albert bandura dalam teori social learningnya.

Hal ini sejalan dengan hasil data KPAI tahun 2019 yang berkaitan dengan kasus kekerasan diindonesia yang sering terjadi dan terlihat pada institusi Pendidikan. Data yang ditampilkan oleh Komisi Nasional Perlindungan Anak, terlihat kasus kekerasan yang terjadi disekolah terdapat 1664 kasus yang terhitung dari tahun 2011-2018. Selanjutnya dibuktikan juga dengan beberapa hasil penelitian yang dilakukan oleh (Kartianti et al., 2020) bahwa di daerah Gonga Pantai, perilaku agresif terlihat pada anak usia 7-9 tahun dengan memunculkan perilaku memukul, memaki ,mencubit, menendang, dan menghina. Selanjutnya penelitian yang dilakukan (Siahaan et al., 2020) dapat diketahui hasil observasi perilaku agresif verbal anak diperoleh $68 \%$ - $100 \%$ dengan kategori tinggi. 34\% - 67\% dapat dikategorikan sedang. 0\% - 33\% dengan kategori rendah. Dengan demikian, berdasarkan perhitungan hasil rata-rata, diperoleh bahwa agresif verbal anak usia 5-6 tahun berada pada kategori sedang.

Berdasarkan beberapa hasil penelitian dan hasil survei kasus kekerasan yang terjadi di Indonesia ini menunjukkan bahwa sangat penting bagi semua kalangan untuk memahami perilaku agresif anak usia dini, faktor penyebab serta penanganannya. Penelitian kali ini peneliti akan mengumpulkan beberapa hasil penelitian dan literatur yang relevan dan terbaru untuk mendeskripsikan perilaku agresif yang dilakukan oleh anak usia dini, faktor yang menjadi penyebab munculnya perilaku agresif anak usia dini, dan penanganan yang bisa diberikan untuk perilaku agresif anak usia dini. 


\section{METODE}

Jenis penelitian yang digunakan adalah studi literatur. Studi literatur adalah metode penelitian yang dilakukan melalui pengumpulan data berdasarkan pencarian informasi menggunakan buku, artikel maupun literature relevan lainnya (Bibby \& McIlroy, 2013). Literature yang digunakan adalah literatur yang berhubungan perilaku agresif anak, faktor penyebab perilaku agresif anak, dan penanganan perilaku agresif anak. Landasan teori digunakan untuk menganalisis bagaimana perilaku agresif anak usia dini.

\section{HASIL DAN PEMBAHASAN}

- Perilaku Agresif Anak

Perilaku agresif adalah suatu perilaku yang bermakna negative karena perilaku ini berarah untuk menyakiti orang lain baik secara fisik maupun psikologis. Perilaku ini adalah wujud dari ketidakpuasan anak terhadap suatu kondisi sehingga anak mengekspresikan perasaan dengan tidak wajar.

Agresivitas adalah bentuk emosi dari perasaan marah atau tindakan merugikan orang lain (Izzaty, 2005) Tindakan yang dimunculkan dapat berupa kekerasan verbal, kekerasan fisik maupun ekspresi wajah dan gerakan tubuh yang mengancam atau merendahkan. Hal ini sejalan dengan pendapat (Tola, 2018) bahwa perilaku agresif yang dilakukan anak usia dini terdiri dari (1) agresif fisik; (2) agresif yang meledak; (3) agresif verbal; dan (4) agresif secara tidak langsung.

Agresif fisik adalah perilaku agresif yang bertujuan untuk menyerang fisik dengan melakukan kekerasan atau melukai orang lain. Agresif fisik dilakukan menggunakan fisik atau objek lain untuk menimbulkan cedera atau ketidaknyamanan pada individu lain (Kim, 2004). Memukul, mencubit, menendang dan menunjukkan tindakan menghina orang lain merupakan beberapa tindakan agresif fisik (Abdul, 2013). Jadi, disimpulkan bahwa agresif fisik merupakan perilaku yang dimaksudkan untuk menyakiti seseorang dan bentuk tindakan fisik, seperti: memukul, mencubit, menendang dan lain sebagainya..

Agresif verbal merupakan perilaku agresif untuk menyerang orang lain secara verbal dengan mengucapkan kata-kata kasar. Contoh dari perilaku agresi verbal diungkapkan oleh (Siahaan et al., 2020) adalah bicara kotor dan kasar, menyebut teman dengan nama hewan, berlagak, memanggil temannya dengan nama orang tua, mengancam, mengejek, membentak.

Agresif meledak adalah perilaku agresif yang dilakukan tanpa alasan seperti marah tanpa alasan (Falah et al., 2020) Sedangkan agresif secara tidak langsung misalnya berbohong pada guru dengan menceritakan anak lain yang melakukan kesalahan (Bos \& Vaughn, 2002)

Perilaku agresif pada umumnya berasal dari hasil mencontoh atau melihat orang lain. Selanjutnya perilaku tersebut ditiru oleh anak atau individu. Perilaku agresif adalah perilaku yang dipelajari dari pola atau dorongan biologis (Bandura \& McClelland, 1977). Sejalan dengan pendapat (Glew et al., 2000) perilaku agresif pada anak merupakan hasil dari perilaku dalam lingkungan keluarga yang dikembangkan oleh orang tua. Orang tua yang menampilkan perilaku hidup dengan berkata kasar, sering memukul, kemungkinan perilaku agresif tersebut akan ditiru dan dikembangkan oleh anak.

Perilaku agresif memiliki karakteristik atau ciri perilaku yaitu; (1) menyakiti atau merusak diri sendiri, orang lain, atau objekobjek penggantinya; (2) tidak diinginkan oleh orang yang menjadi objek sasarannya; (3) seringkali menjadi perilaku yang melanggar norma sosial (Arifah \& Widyastuti, 2018). Jadi dapat disimpulkan perilaku agresif memiliki ciri merugikan individu pelaku maupun orang lain.

\section{- Faktor Penyebab Perilaku Anak Usia Dini}

Perilaku agresif yang dilakukan anak terjadi disebabkan oleh beberapa faktor. Ada faktor internal maupun faktor eksternal (Nugraheni, 2013). Adapun faktor internal maupun eksternalnya yaitu; (1) lingkungan terdekat anak yaitu keluarga; (2) lingkungan kedua anak yaitu; (3) lingkungan pergaulan antara anak dengan teman; (4) frustasi, provokasi, dan imitasi; (5) penyebab situasional; (6) sifat kepribadian; (7) kompetisi; (8) faktor biologis; (9) faktor ekonomi; (9) video games (Arifah \& Widyastuti, 2018).

Pendapat (Gentile et al., 2009) menyatakan bahwa penyebab perilaku agresif anak terbagi menjadi 5 hal yaitu; (1) Komunikasi orang tua yang buruk; (2) anak meniru perilaku kekerasan orang tua; (3) pengalaman anak menjadi korban kekerasan; (4) anak terpapar aksi-aksi kekerasan di media sosial; (5) anak terpapar konten seksualitas. Berdasarkan pendapat gentile maka peneliti akan menghubungkan dengan beberapa penelitian yang relevan dibawah ini 
Lingkungan keluarga merupakan faktor penyebab utama karena keluarga merupakan lingkungan terdekat anak. Penelitian yang menunjukkan bahwa faktor keluarga merupakan penyebab dilakukan oleh (Pratiwi et al., 2019). Hasil penelitian menunjukkan terdapat hubungan positif atau searah antara pola asuh otoriter dengan perilaku agresif anak usia 5-6 tahun yaitu semakin tinggi tingkat pola asuh otoriter maka semakin tinggi pula perilaku agresif anak. Orang tua yang mengasuh anak dengan pola asuh otoriter kemungkinan besar anaknya akan memunculkan perilaku agresif. Hasil penelitian ini juga sejalan dengan teori Vygotsky bahwa pengaruh social dan kebudayaan memberikan pengaruh pada pembentukan keyakinan, nilai, norma kesopanan (Suryana \& Yulsyofriend, 2012)

Komunikasi antara orang tua dengan anak juga mempengaruhi perilaku agresif. Terlihat dari penelitian yang dilakukan oleh (Siahaan et al., 2020). Hasil penelitian menunjukkan terdapat pengaruh komunikasi orang tua terhadap perilaku agresif. Orang tua yang dirumahnya berkomunikasi dengan anak dengan cara tidak terbuka, otoriter, mengabaikan anak, menyebabkan anak memunculkan perilaku agresif verbal. Dan dari penelitian dari beberapa jenis komunikasi, komunikasi satu arah memiliki pengaruh tertinggin menyebabkan perilaku agresif verbal pada anak.

Hubungan yang tidak harmonis dalam keluarga yang berujung perceraian juga menjadi salah satu penyebab perilaku agresif anak. Hal ini senada dengan hasil penelitian (Aulia, 2020) yaitu perceraian membuat anak memunculkan perilaku agresif, dan sangat penting bagi orang tua dan guru saling bekerja sama untuk memperhatikan dan memberikan kasih sayang yang cukup, memenuhi fasilitas anak.

Anak-anak yang dibesarkan dalam lingkungan kemiskinan atau kekurangan secara ekonomi akan kemungkinan besar akan memiliki perilaku yang agresif. Hal ini dibuktikan dengan penelitian yang dilakukan oleh (Falah et al., 2020) menunjukan bahwa anak yang berasal dari keluarga dengan status sosial ekonomi yang rendah cenderung memiliki perilaku yang agresif. Pola perilaku agresif yang dimunculkan ada yang verbal, fisi, maupun tidak langsung. Perilaku agresif yang dimunculkan disebabkan dari dari lingkungan yang kurang kondusif dan pemenuhan kebutuhan yang tidak terpenuhi.

Video games yang menampilkan adegan kekerasan juga menjadi pemicu muncul perilaku agresif anak. Karena pada dasarnya anak usia dini sifatnya adalah peniru ulung maka dia akan meniru apa yang menurutnya menyenangkan. Berdasarkan penelitian yang dilakukan oleh (Rohman, 2018) menunjukkan hasil bahwa anak yang kecanduan game online yaitu game Mobile Legend: Bang-Bang akan memiliki pengaruh yang signifikan terhadap agresifitas anak, dengan analisis data statistik didapatkan hasil bahwa semakin tinggi tingkat kecanduan anak terhadap game online, semakin tinggi pula tingkat agresivitas anak tersebut.

Dari beberapa hasil penelitian dapat simpulka bahwa faktor yang menyebabkan perilaku agresif pada anak usia dini ada dua yaitu faktor internal dan faktor eksternal. Faktor internal berasal dari dalam diri anak, sedangkan faktor eksternal berasal dari luar diri anak seperti lingkungan luar.

\section{- Penanganan Perilaku Agresif Anak Usia Dini}

Perilaku agresif anak usia dini perlu untuk ditangani dan dikendalikan. Maka dari itu untuk menangani perilaku agresif anak perlu intervensi dari semua pihak yaitu orang tua, guru, dan lingkungan masyarakat. Upaya yang bisa dilakukan untuk mengatasi perilaku agresif pada anak dapat digunakan cara seperti: lebih memahami dan menerima pribadi anak, menciptakan pembelajaran yang menyenangkan, dan aktif, mengembangkan katarsis (penyaluran pada kegiatan positif), mengembangkan strategi memperagakan/pelatihan, menciptakan lingkungan nonagresif, mengembangkan sikap empati anak, dan langkah terakhir jika semua tidak ada jalan lain yaitu menerapkan punishment (hukuman) (Setiawan, 2013)

Beberapa penelitian yang membuktikan sebuah tindakan yang bertujuan untuk menangani perilaku agresif anak dilakukan oleh (Grahani, 2017) dengan hasil penelitian menunjukkan bahwa kegiatan parenting skill efektif dalam menangani perilaku agresi pada anak.karena kegiatan parenting skill dapat meningkatkan pemahaman dan keterampilan orang tua dalam menerapkan pola asuh. Kegiatan ini dilakukan karena pola asuh masih menjadi hal yang tidak diperhatikan oleh orang tua, sehingga pola asuh yang diberikan kepada anak tidak optimal dalam mendukung tumbuh kembang anak (Yulia et al., 2021). Pada dasarnya pola asuh yang diberikan orang tua pada anak harus disesuaikan dengan usia dan kebutuhanan anak. Hal ini sejalan dengan pendapat (Dewi, 2017) bahwa dalam tahapan pengasuhan orang tua perlu menyesuaikan 
dengan tingkatan usia anak. Usia 0-6 tahun anak sangat membutuhkan kasih sayang dan orang tua menjadi contoh mutlak bagi anak dalam perilaku sehari-hari, usia 7-14 tahun orang tua mendidik dengan konsisten penuh arahan dan tetap dilandasi kasih sayang, usia 15-21 orang tua mendidik dengan cara memandang anak sejajar/berteman dan pada usia 21 tahun keatas orang tua berperan sebagai sumber nasihat.

Guru sebagai orang tua kedua anak disekolah juga memerlukan strategi untuk menangani perilaku agresif anak. Hasil penelitian (Mustika, 2020) membuktikan bahwa strategi guru seperti guru merangkul anak saat melakukan tindakan agresif, guru membujuk dan memberikan nasehat yang baik pada anak, guru juga harus bersikap lemah lembut dalam menghadapi anak yang berperilaku agresif efektif dalam mereduksi perilaku agresif anak dengan baik. saat anak memunculkan perilaku agresif guru tentunya harus memberikan intervensi terhadap anak. Intervensi yang diberikan bisa berbentuk pencegahan maupun penanganan. Selain itu guru juga perlu memberikan sikap dan motivasi yang positif, hal ini sejalan dengan pendapat (Suryana, 2013) bahwa sikap positif dan motivasi guru berpengaruh pada hasil belajar anak. Anak anak yang mendapat pengalaman yang menyenangkan dari orang lain akan memberikan respon positif kepada orang tersebut (Suryana, 2012). Anak-anak yang memunculkan perilaku agresif perlu ditangani dengan sikap positif dari guru dan pemberian motivasi agar sikap tersebut bisa diminimalisir atau bahkan dihilangkan.

Peran guru sangat penting dalam menangani perilaku agresif anak, karena guru memiliki peranan dalam membentuk karakter dan temperamen yang baik untuk anak-anak di Indonesia (Suryana, 2012a). Pembelajaran yang memberikan pengaruh positif dalam membentuk karakter dan temperamen pada anak tentu harus didukung oleh lingkungan yang kondusif. Lingkungan pembelajaran hendaknya di setting agar menarik, menyenangkan, aman, dan nyaman bagi anak. Penataan ruang diatur agar anak dapat berinteraksi dengan guru, pengasuh, dan anak lain. (Suryana \& Rizka, 2019). Beberapa strategi, metode, dan cara yang bisa dilakukan guru telah dijelaskan dalam beberapa hasil penelitian dibawah ini.

Kegiatan menggambar pada anak bisa menangani perilaku agresif pada anak. Hasil penelitian yang dilakukan oleh (Fatmawati \& Khusnal, 2014) menunjukkan hasil ada perbedaan yang signifikan tentang perilaku agresif anak usia 3-6 tahun sebelum dan sesudah diberikan aktivitas menggambar. Hal ini menunjukkan ada pengaruh dari aktivitas menggambar terhadap perilaku agresif anak sehingga aktivitas menggambar bisa diterapkan oleh orang tua dan guru dalam menangani perilaku agresif anak. Aktivitas menggambar bisa digunakan untuk menyalurkan emosi dan perasaan anak secara positif.

Stimulasi perkembangan sosial anak khususnya empati juga berpengaruh dalam menangani perilaku agresif anak. Hal ini sejalan dengan hasil penelitian (Zahro, 2019) menunjukkan bahwa pelatihan empati yang dilakukan melalui kartu emosi memberikan pengaruh positif pada perilaku menolong dan pengaruh negative perilaku agresif pada kelompok eksperimen maupun kelompok kontrol. Pelatihan yang diberikan faktanya mampu untuk meningkatkan perilaku menolong anak dan sebaliknya mampu menurunkan perilaku agresif pada anak usia dini.

Menerapkan metode bermain peran sebagai bentuk pengekspresian perasaan anak. Hasil penelitian (Wijayati, 2016) menunjukkan bahwa dengan diterapkannya metode bermain peran, perilaku agresif anak berkurang. Hasil olahan data penelitian menunjukkan adanya penurunan setelah diterapkan metode bermain peran terhadap perilaku agresif anak yaitu dari $83 \%$ menjadi $43 \%$. Hal ini dapat dilihat dari adanya perubahan perilaku anak ke arah yang lebih baik seperti anak tidak memukul, tidak mencubit, tidak mendorong, tidak mengejek dan tidak mengambil paksa barang temannya lagi.

Hasil penelitian (Solichah, 2020) menunjukkan bahwa storytelling mampu menurunkan perilaku agresif pada anak. Hasil dari analisis grafik membuktikan jika terdapat perbedaan perilaku subjek sebelum dan sesudah diberikan intervensi berupa storytelling. Hal ini senada dangan pendapat yang menyebutkan bahwa metode bercerita atau storytelling dapat membuat anak-anak dengan mudah memahami nilai dan norma yang positif.

Hasil penelitian studi kasus yang dilakukan (Fajri, 2020) menunjukkan hasil bahwa penggunaan intervensi token ekonomi mampu menurunkan perilaku agresif pada anak usia dini. token ekonomi merupakan salah satu teknik modifikasi perilaku yang bisa diterapkan pada anak. Intervensi token ekonomi dilakukan dengan cara memberikan beberapa serangkaian tes psikologi pada anak. Intervensi token ekonomi juga memerlukan kerjasama antara orang tua dan guru. 
Berdasarkan beberapa hasil penelitian yang dilakukan dapat disimpulkan bahwa dalam upaya penanganan perilaku agresif anak usia dini dibutuhkan kerjasama dari berbagai pihak. Sebelum memberikan intervensi ada baiknya bagi orang tua dan guru menggali terlebih dahulu penyebab dari munculnya perilaku agresif anak sehingga penanganan yang diberikan dapat disesuaikan dengan faktor penyebabnya.

\section{KESIMPULAN DAN SARAN \\ Kesimpulan}

Perilaku agresif anak usia dini merupakan salah satu bentuk dari tidak tepatnya anak dalam belajar sosial, hal ini dikarenakan perilaku ini adalah suatu bentuk ekspresi emosi negative yang mana bisa merugikan diri sendiri maupun orang lain. Faktor yang mempengaruhi terjadinya perilaku agresif anak ada dua yaitu faktor internal maupun eksternal. Penanganan perilaku agresif pada anak usia dini adalah suatu bentuk tindakan orang tua dan guru dalam mengatasi dan mengendalikan perilaku agresif anak.

Saran

Saran yang bisa diberikan berdasarkan hasil temuan pada penelitian ini yaitu perlunya pola asuh yang tepat untuk diterapkan orang tua kepada anak, dan menciptakan lingkungan kondusif dimana bisa memunculkan perilaku positif pada anak serta perlunya komunikasi dan Kerjasama antara orang tua, guru dan masyarakat.

\section{DAFTAR PUSTAKA}

Abdul, A. R. (2013). Psikologi Sosial: Integrasi Pengetahuan Wahyu dan Pengetahuan Empirik. Jakarta: Rajawali Pers.

Arifah, I. M., \& Widyastuti, A. (2018). Konseling Behavioral Dalam Mengatasi Perilaku Agresif Anak Usia Dini. AlIsyraq: Jurnal Bimbingan, Penyuluhan, Dan Konseling Islam, I(2).

Ariyanti, T. (2016). Pentingnya Pendidikan Anak Usia Dini Bagi Tumbuh Kembang Anak The Importance Of Childhood Education For Child Development. Dinamika Jurnal Ilmiah Pendidikan Dasar, 8(1).

Aulia, P. (2020). Dampak Perceraian Orang Tua terhadap Perilaku Agresif Anak Usia 45 Tahun di PAUD Bina Bangsa Kampung Tongah Pasaman. Jurnal Pendidikan Tambusai, 4(3), 3181-3187.
Bandura, A., \& McClelland, D. C. (1977). Social learning theory (Vol. 1). Englewood cliffs Prentice Hall.

Berkowitz, L. (1995). Agresi: Sebab Akibat. Jakarta: Pustaka Binaman Pressindo.

Bibby, S., \& McIlroy, T. (2013). Literature in language teaching: What, why, and how. The Language Teacher, 37(5), 1921.

Bos, C. S., \& Vaughn, S. (2002). Strategies for teaching students with learning and behavior problems. ERIC.

Dewi, K. S. (2017). Penanganan Perilaku Agresif Anak. Universitas Diponegoro.

Fajri, R. I. (2020). Studi Kasus: Penggunaan Intervensi Token Ekonomi Untuk Menurunkan Perilaku Agresif Pada Anak Usia Dini. Coution: Journal of Counseling and Education, 1(2), 27-35.

Falah, V. Y., Fitriasari, N. S., \& Mashudi, E. A. (2020). Perilaku Agresif Anak Usia Dini Yang Ebrasal Dari Keluarga Berstatus Sosial Ekonomi Lemah. Universitas Pendidikan Indonesia.

Fatmawati, A., \& Khusnal, E. (2014). Pengaruh Aktivitas Menggambar terhadap Perilaku Agresif Anak Usia 3-6 tahun di PAUD Sariharjo Ngaglik Sleman. STIKES'Aisyiyah Yogyakarta.

Gentile, D. A., Anderson, C. A., Yukawa, S., Ihori, N., Saleem, M., Ming, L. K., Shibuya, A., Liau, A. K., Khoo, A., \& Bushman, B. J. (2009). The effects of prosocial video games on prosocial behaviors: International evidence from correlational, longitudinal, and experimental studies. Personality and Social Psychology Bulletin, 35(6), 752763.

Glew, G., Rivara, F., \& Feudtner, C. (2000). Bullying: children hurting children. Pediatrics in Review, 21(6), 183-190.

Grahani, F. O. (2017). Efektivitas Parenting Skill dalam Menangani Perilaku Agresi Anak Usia Dini. Jurnal Psikologi: Media Ilmiah Psikologi, 15(1), 25-30.

Izzaty, R. E. (2005). Mengenali Permasalahan Perkembangan Anak Usia TK. Jakarta: Depdiknas. 
Kartianti, S., Laluba, F., Tjepa, S., Laluba, R., Halimongo, K., \& Balitang, Y. (2020). Mereduksi Perilaku Agresif Anak Melalui Bimbingan Kelompok Dengan Permainan Tradisional Di Daerah Pesisir. Jurnal Pendidikan Dan Konseling (JPDK), 2(1), 16-24.

Kim, S. J. (2004). A study of personal and environmental factors influencing bullying. Munchen.

Laila, Q. N. (2015). Pemikiran Pendidikan Moral Albert Bandura. MODELING: Jurnal Program Studi PGMI, 2(1), 2136.

Mansur, R. (2018). Lingkungan yang mendidik sebagai wahana pembentukan karakter anak. Vicratina: Jurnal Pendidikan Islam, 2(2), 33-46.

Mustika, H. (2020). Strategi Guru Dalam Menangani Perilaku Agresif Anak Usia Dini Di Tk It Mon Kuta Banda Aceh. Jurnal Ilmiah Mahasiswa Pendidikan Anak Usia Dini, 5(2).

Nesbit, S. M., Conger, J. C., \& Conger, A. J. (2007). A quantitative review of the relationship between anger and aggressive driving. Aggression and Violent Behavior, 12(2), 156-176.

Nugraheni, L. (2013). Faktor-Faktor yang Memengaruhi Perilaku Agresif Anak Usia Dini dan Penanganannya Oleh Konselor di TK Bina Anak Sholeh (BAS) Tuban. Jurnal BK Unesa, 4(1).

Pratiwi, D. F., Hafidah, R., \& Pudyaningtyas, A. R. (2019). Pola Asuh Otoriter Dengan Perilaku Agresif Anak Usia 5-6 Tahun. Kumara Cendekia, 7(1), 79-88.

Rohman, K. (2018). Agresifitas Anak Kecanduan Game Online. Martabat, 2(1), 155-172.

Setiawan, A. (2013). Penanganan Perilaku Agresif pada Anak. Jassi Anakku, 9(1), 89-96.

Siahaan, Y. E., Sutapa, P., \& Yus, A. (2020). Pengaruh Komunikasi Orangtua terhadap Perilaku Agresif verbal Anak Usia 5-6 Tahun. Jurnal Obsesi: Jurnal Pendidikan Anak Usia Dini, 5(2), 14721486.
Solichah, N. (2020). Storytelling untuk mengatasi perilaku agresif anak. AlQalb: Jurnal Psikologi Islam, 11(2), 112.

Suryana, D. (2012a). Character Building for Young Children Based on the Value of Cultural Universisty of Indonesia. Universitas Neger Padang.

Suryana, D. (2012b). Profesionalisme Pendidik dan Penyelenggaraan Pendidikan Anak Usia Dini di Kota Padang. Universitas Negeri Padang.

Suryana, D. (2013a). Pendidikan Anak Usia Dini: Teori Dan Praktik Pembelajaran. Universitas Negeri Padang.

Suryana, D. (2013b). Pengetahuan tentang strategi pembelajaran, sikap, dan motivasi guru. Jurnal Ilmu Pendidikan, 19(2).

Suryana, D. (2014). Kurikulum Pendidikan Anak Usia Dini Berbasis Perkembangan Anak. Jurnal Pesona: Jurnal Pendidikan Dasar Dan Humaniora, 2(1), 65-72.

Suryana, D. (2016). Pendidikan Anak Usia Dini: Stimulasi \& Aspek Perkembangan Anak. Prenada Media.

Suryana, D., Hartinah, U., \& Mayar, F. (2018). Efektivitas Mencetak Percikan Daun Terhadap Perkembangan Motorik Halus Anak Di Taman Kanak-Kanak Aisyiyah Suayan. Jurnal Usia Dini, 4(2), 55-66.

Suryana, D., \& Rizka, N. (2019). Manajemen pendidikan anak usia dini berbasis akreditasi lembaga. Universitas Negeri Padang.

Suryana, D., \& Yolanda, E. (2018). Aggressive Behavior In Children Be Reviewed From Parenting Style. Universitas Negeri Padang.

Suryana, D., \& Yulsyofriend, Y. (2012). Efektivitas Outbound dalam Pengembangan Kepercayaan Diri pada Anak TK Pertiwi VI Kota Padang. Universitas Negeri Padang.

Tola, Y. P. (2018). Perilaku Agresif Anak Usia Dini di Lihat dari Pola Asuh Orang Tua. Jurnal Buah Hati, 5(1), 1-13.

Wijayati, N. (2016). Pengunaan Metode Bermain Peran Dalam Mengurangi 
Perilaku Agresifitas Anak TK Desa Sewulan Tahun Ajaran 2015/2016. Prosiding Ilmu Pendidikan, 1(2).

Yulia, R., Suryana, D., \& Safrizal, S. (2021). Manipulatif Tantrum: Strategi untuk Mewujudkan Keinginan Anak. Golden Age: Jurnal Ilmiah Tumbuh Kembang Anak Usia Dini, 6(1), 1-10.

Zahro, I. F. (2019). Pengaruh Pelatihan Empati Melalui Kartu Ekspresi Emosi Terhadap Perilaku Menolong Dan Perilaku Agresif Pada Anak Prasekolah. JCE (Journal of Childhood Education), 1(1). 